\title{
The influence of biological and environmental factors on the stable isotopic composition of ostracods - the Late Pleistocene record from Lake Albano, Central Italy
}

\author{
Claudio A. BELIS* and Daniel ARIZTEGUI ${ }^{1)}$ \\ CNR-Istituto per lo Studio degli Ecosistemi, Largo Tonolli 50, 28922 Verbania, Italy \\ present address: via Pace 19, 23020 Montagna in V.na, (SO), Italy \\ ${ }^{1)}$ Institute Forel and Dept. of Geology \& Paleontology, University of Geneva, Rue des Maraîchers 13, 1205 Geneva, Switzerland \\ *e-mail corresponding author: claudio.belis@provincia.so.it
}

\begin{abstract}
The stable oxygen and carbon isotopic composition of ostracod valves is the result of the interaction of several variables. Understanding and identifying the biological and ecological factors influencing the life of these animals improves the interpretation of isotopical data, and leads to better paleoenvironmental reconstructions. Ostracod biostratigraphy and determinations of oxygen and carbon stable isotopes on ostracod valves were carried out on a short sequence of the Last Glacial Maximum from Lake Albano (Central Italy). The oxygen isotopic composition of adults of Candona neglecta ranged between 0.5\% and 1.5\%o, and in Ilyocypris bradyi between $-2 \%$ and $-0.5 \%$. Isotopic values from adults of $\mathrm{C}$. neglecta fell within the range $-1.5 \%$ o to $-0.8 \%$ when corrected for vital effect. The carbon isotopic signal ranged from $9.4 \%$ to $10.8 \%$ in adults and juveniles of C. neglecta, and from $9.8 \%$ o to $11.3 \%$ in I. bradyi. Differences between left/right valve and gender were negligible, whereas there appeared to be a marked influence of life stage and species-specific factors related to vital effect and differences in microhabitat and seasonality. We combined analyses on carbon and oxygen isotopes with information deriving from ostracod ecology to reconstruct short term oscillations in past lake water level. Seasonal changes in either the temperature or the isotopic composition of the lake water were also identified. Relatively high $\delta^{18} O$ values in ostracod valves were probably associated with the lake location and source of moisture, while high $\delta^{13} \mathrm{C}$ values were most probably related to the input of volcanic $\mathrm{CO}_{2}$ into the lake.
\end{abstract}

Key words: ostracods, stable isotopes, Lake Albano, Latest Pleistocene, autoecology

\section{INTRODUCTION}

Oxygen stable isotopes in lacustrine carbonates are one of the most commonly used proxies in palaeoclimatic reconstructions (e.g., McKenzie \& Eberli 1987; Talbot \& Kelts 1990; Teranes et al. 1999a). They have been successfully applied in quantitative reconstructions of lake water sources, palaeotemperature and atmospheric circulation patterns (e.g., McKenzie \& Hollander 1993; McKenzie 1993; Teranes \& McKenzie 2001). The oxygen isotope composition of modern lake waters is determined by a combination of meteorology, local hydrological balance, and geographical setting (Schwalb et al. 1994). In most cases carbonates precipitating within a lake (authigenic) record the actual water isotopic composition. However, this signal may eventually be overprinted by additional factors such as natural or anthropogenically-induced eutrophication (e.g., Mullins 1998; Teranes et al. 1999b). A good understanding of the lake system is then crucial in separating these often concurrent factors. Biogenically-produced calcite such as that precipitated by benthic ostracods, in particular, provides an isotopic record that is free of potential mixing with clastic carbonates. In addition, sublittoral ostracods dwell in environments in which water temperatures remain unaffected by seasonal changes (Lister
1988; Schwalb 2003). Quantitative temperature reconstruction, however, is not straightforward, since many factors may affect the original signal (e.g., valve redeposition, diagenetic processes, sample treatment). In addition, it has been established that isotopic fractionation during valve formation differs among species, inducing systematic offsets that have been referred to as "vital offsets" (Urey et al. 1951). Furthermore, specific differences in micro-habitat and seasonality have been found to affect the valve isotopic signal (e.g., von Grafenstein et al. 1999).

The carbon isotopic composition of calcite is insensitive to changes in temperature; nevertheless, $\delta^{13} \mathrm{C}$ in ostracod valves has been used to evaluate lacustrine productivity (Lister 1998), to detect changes in the catchment vegetation (Schwalb \& Dean 1998) and variations in lake water balance (von Grafenstein et al. 2000) and together with oxygen isotopic signature to assess the life span of aquatic environments (Schwalb et al. 2002).

The $\delta^{13} \mathrm{C}_{\text {DIC }}$ (dissolved inorganic carbon) depends on the isotopic signature of the bicarbonate imported into the lake, the net deposition of organic matter produced in the lake, and the strength of $\mathrm{CO}_{2}$ exchange at the lake's surface (von Grafenstein et al. 2000). Thus, it is clear that these physical and biological processes have 

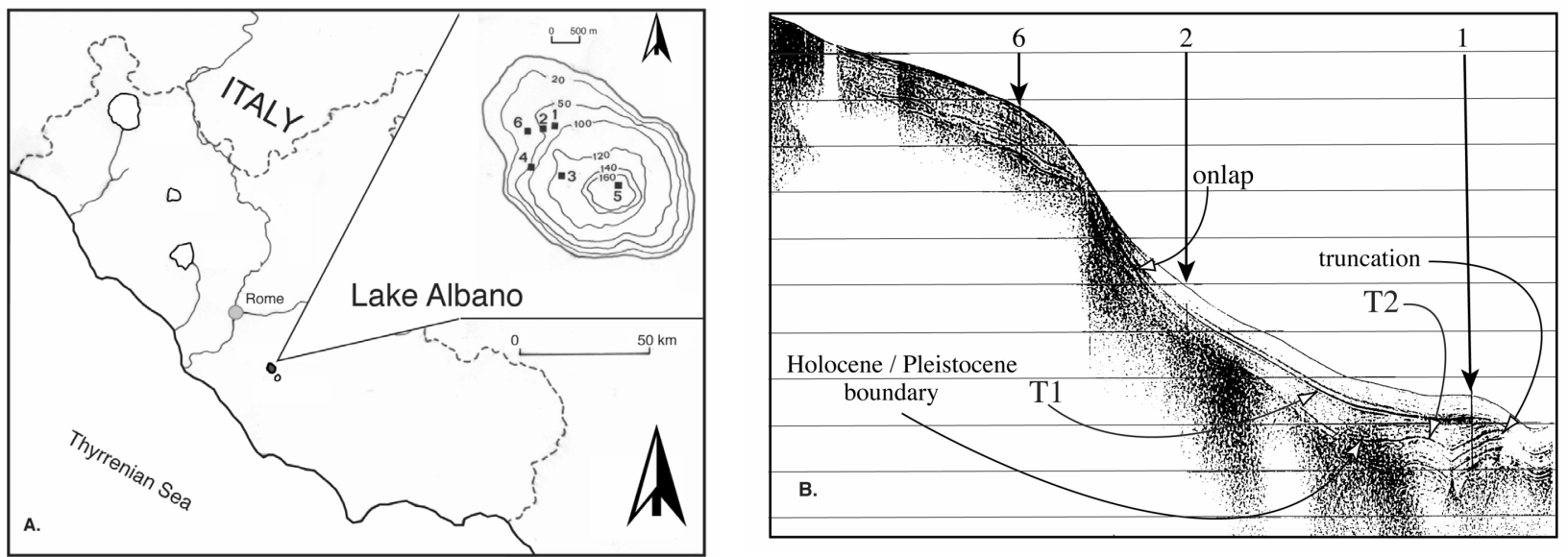

Fig. 1. Study area and stratigraphic framework: A. Map of central Italy showing the most important volcanic lakes and bathymetric map of Lake Albano indicating core positions. B. High resolution seismic profile containing the position of site 2 (this study), 1 and 6 (modified from Chondrogianni et al. 2004). The interpreted seismic reflectors allow inter-site correlation and the extrapolation of the chronological model among coring sites.

to be evaluated and quantified in order to properly assess the environmental meaning of this proxy.

The purposes of this paper are: a) to constrain the influence of species, gender, life stage and left/right valve on $\delta^{18} \mathrm{O}$ and $\delta^{13} \mathrm{C}$ in ostracods of a sedimentary sequence from Lake Albano (Central Italy), b) to identify changes in lake water level and lake water temperature using ostracod biostratigraphy and c) to discuss quantitative estimations of changes in past lake water temperatures and of major changes in lake water $\delta^{18} \mathrm{O}$.

\subsection{The study site}

Lake Albano (Italy) is an ideal site for the aims of this study because its environmental evolution since the latest Pleistocene has been thoroughly examined using a multi-proxy approach within the framework of the E.U. project PALICLAS: Paleoenvironmental Analyses of Italian lakes and Adriatic sediments (Guilizzoni \& Oldfield 1996). Previous studies of the sub-fossil ostracod fauna between 28 and $17 \mathrm{Kyr}$ cal BP of this lake furnished unique paleoecological data that were fully constrained with independent proxy data (Guilizzoni et al. 2000; Chondrogianni et al. 2004).

Lake Albano $\left(41^{\circ} 45^{\prime} \mathrm{N}, 12^{\circ} 41^{\prime} \mathrm{E}\right)$ is a crater lake located $25 \mathrm{~km}$ southeast of Rome (Fig. 1). The lake has maximum and mean depths of 175 and $77 \mathrm{~m}$, respectively, and a surface area of $6 \mathrm{~km}^{2}$ within $\mathrm{ca} 3.7 \mathrm{~km}^{2}$ catchment. It is a hydrologically-closed crater basin mostly fed by local precipitation and submerged springs. While the water exchange between the Albano hydrostructure and the deeper karstic aquifer is insignificant, chemical and isotopical analyses on springs in the surrounding area have identified a gas phase consisting mainly of $\mathrm{CO}_{2}$ of deep origin (Boni et al. 1995). Due to its funnel shape and depth, Lake Albano is normally strongly stratified. Its water column shows a thick thermocline from $c a 25 \mathrm{~m}$ to $c a 55 \mathrm{~m}$ and an anoxic hypolimnion extending from that depth to the lake bottom (Cioni et al. 2003).

An artificial channel in the south-eastern side of the lake was dug in Roman times (390 BC), apparently to cope with a major rise in lake water level that was menacing the surrounding human settlements (Mastrigli 1964). A more detailed description of the study site is available elsewhere (Trigila 1995; Chondrogianni et al. 1996a).

Sedimentary cores were retrieved in six different sites (Fig. 1). Detailed multi-proxy analyses were performed in sites 1 and 6 at $70 \mathrm{~m}$ and $30 \mathrm{~m}$ water depth, respectively. Core dating and correlation indicate that the sediments from site 6 represent almost exclusively the interval from 24 to $17 \mathrm{Kyr}$ cal BP, whereas site 1 spans Late Pleistocene and Holocene sediments younger than $28 \mathrm{Kyr}$ cal BP (Guilizzoni et al. 2000; Chondrogianni et al. 2004). Site 2, located in an intermediate position between sites 1 and 6, was selected for this study in order to better link the sequences from those sites and provide a clearer picture of the dynamics of the lake through time (i.e. lake level variations).

\section{MATERIAL AND METHODS}

Core PALB94 2B was retrieved in position 2 at 55 $\mathrm{m}$ water depth (Fig. 1). More details of lake sediments geometry obtained from high resolution seismic profiles and core analyses are thoroughly described in Chondrogianni et al. (1996b) and Guilizzoni et al. (2000).

Intervals containing ostracod valves were identified through a preliminary visual and microscopic inspection of the sediments. The analysis was then focused on the lowermost $45 \mathrm{~cm}$ of core PALB94 2B $(830-875 \mathrm{~cm}$ core depth), hereafter "ostracod sequence", the only one with a well-preserved ostracod community. The sampling strategy for determining ostracod assemblages followed major changes in core lithology. Isotopic 
Tab. 1. Isotope data from ostracod valves in \%o PDB, core PALB94 2B.

\begin{tabular}{|c|c|c|c|c|c|c|}
\hline \multicolumn{2}{|c|}{ Sample Species } & \multirow[t]{2}{*}{ left/right } & \multirow{2}{*}{$\begin{array}{c}\text { core depth } \\
830.5\end{array}$} & \multirow{2}{*}{$\frac{\delta^{13} \mathrm{C}}{10.2}$} & \multirow{2}{*}{$\frac{\delta^{18} \mathrm{O}}{-0.3}$} & \multirow{2}{*}{$\frac{\text { number of valves }}{9}$} \\
\hline 1 & C. neglecta juveniles & & & & & \\
\hline 2 & I. bradyi & & 830.5 & 10.3 & -1.2 & 8 \\
\hline 3 & C. neglecta females & & 832.5 & 10.5 & 1.1 & 3 \\
\hline 4 & I. bradyi & & 832.5 & 10.5 & -2.1 & 5 \\
\hline 5 & I. bradyi & & 832.5 & 11.1 & -1.6 & 5 \\
\hline 6 & C. neglecta juveniles & & 832.5 & 9.4 & -0.9 & 9 \\
\hline 7 & C. neglecta juveniles & & 834.5 & 10.9 & 0.1 & 10 \\
\hline 8 & I. bradyi & & 834.5 & 9.8 & -1.7 & 8 \\
\hline 9 & C. neglecta adults & & 847.5 & 9.7 & 0.9 & 7 \\
\hline 10 & C. neglecta adults & & 847.5 & 10.0 & 0.8 & 7 \\
\hline 11 & C. neglecta females & & 847.5 & 10.3 & 1.4 & 5 \\
\hline 12 & C. neglecta females & & 847.5 & 10.4 & 1.3 & 5 \\
\hline 13 & C. neglecta females & & 847.5 & 9.4 & 1.0 & 5 \\
\hline 14 & C. neglecta females & & 847.5 & 10.5 & 1.2 & 5 \\
\hline 15 & C. neglecta males & & 847.5 & 9.8 & 1.2 & 5 \\
\hline 16 & C. neglecta males & & 847.5 & 9.5 & 1.1 & 5 \\
\hline 17 & I. bradyi & & 847.5 & 11.3 & -0.9 & 5 \\
\hline 18 & C. neglecta juveniles & & 847.5 & 10.3 & 1.4 & 7 \\
\hline 19 & C. neglecta females & & 862.5 & 10.5 & 1.5 & 6 \\
\hline 20 & C. neglecta females & & 862.5 & 10.5 & 0.9 & 5 \\
\hline 21 & C. neglecta females & & 862.5 & 10.3 & 1.1 & 5 \\
\hline 22 & C. neglecta females & & 862.5 & 9.9 & 1.2 & 5 \\
\hline 23 & C. neglecta males & & 862.5 & 10.2 & 1.2 & 6 \\
\hline 24 & C. neglecta males & & 862.5 & 9.9 & 1.1 & 7 \\
\hline 25 & I. bradyi & & 862.5 & 10.6 & -1.0 & 5 \\
\hline 26 & I. bradyi & & 862.5 & 10.5 & -0.1 & 6 \\
\hline 27 & C. neglecta juveniles & & 862.5 & 10.7 & 1.2 & 7 \\
\hline 28 & C. neglecta juveniles & & 862.5 & 9.5 & 1.2 & 5 \\
\hline 29 & C. neglecta females & & 872 & 9.2 & 0.7 & 5 \\
\hline 30 & C. neglecta females & $\mathrm{R}$ & 872 & 9.7 & 0.7 & 5 \\
\hline 31 & C. neglecta females & $\mathrm{R}$ & 872 & 9.8 & 0.6 & 5 \\
\hline 32 & C. neglecta females & $\mathrm{R}$ & 872 & 10.2 & 0.8 & 6 \\
\hline 33 & C. neglecta females & $\mathrm{R}$ & 872 & 9.5 & 0.6 & 6 \\
\hline 34 & C. neglecta females & $\mathrm{L}$ & 872 & 10.3 & 0.7 & 5 \\
\hline 35 & C. neglecta females & $\mathrm{L}$ & 872 & 10.7 & 1.1 & 6 \\
\hline 36 & C. neglecta females & $\mathrm{L}$ & 872 & 9.5 & 0.8 & 6 \\
\hline 37 & C. neglecta females & $\mathrm{L}$ & 872 & 9.8 & 0.7 & 5 \\
\hline 38 & C. neglecta females & & 872 & 10.2 & 0.8 & 6 \\
\hline 39 & C. neglecta males & $\mathrm{R}$ & 872 & 10.7 & 0.8 & 5 \\
\hline 40 & C. neglecta males & $\mathrm{L}$ & 872 & 10.6 & 0.7 & 6 \\
\hline 41 & C. neglecta males & $\mathrm{L}$ & 872 & 10.7 & 0.8 & 5 \\
\hline 42 & C. neglecta males & $\mathrm{R}$ & 872 & 10.3 & 0.8 & 6 \\
\hline 43 & C. neglecta males & & 872 & 10.1 & 0.9 & 5 \\
\hline 44 & I. bradyi & & 872 & 10.3 & -0.5 & 5 \\
\hline 45 & I. bradyi & & 872 & 10.2 & -0.4 & 6 \\
\hline 46 & I. bradyi & & 872 & 10.5 & -0.8 & 6 \\
\hline 47 & I. bradyi & & 872 & 10.4 & -0.3 & 5 \\
\hline 48 & C. neglecta juveniles & & 872 & 10.6 & 0.9 & 8 \\
\hline \multirow[t]{2}{*}{49} & C. neglecta juveniles & & 872 & 9.6 & 1.0 & 5 \\
\hline & TOTAL & & & & & 287 \\
\hline
\end{tabular}

analyses were carried out in only four of these sections representing different ostracod communities and containing the largest number of valves of the species under study. This improved the strength of the results by enabling the analyses to be replicated (Tab. 1).

Valves were sorted, cleaned, identified and counted under a binocular microscope $(40 \times-100 \times)$ from selected samples taken every 5 to $10 \mathrm{~cm}$. Valves were cleaned using a brush and distilled water; no chemical pre-treatment was performed.

Oxygen and Carbon stable isotopes were measured on 49 samples consisting of 3 to 10 valves (most commonly between 5 and 7). The stable isotope composition of 287 valves of the species Candona neglecta and Ilyocypris bradyi was measured by reaction with $100 \%$ orthophosphoric acid at $90{ }^{\circ} \mathrm{C}$ in an automated common acid-bath connected to a triple-collector VG Isogas precision isotope ratio mass spectrometer (PRISM). Results are expressed in delta notation as per mil deviation from the international standard V-PDB $\left(\delta^{18} \mathrm{O}\right.$ and $\left.\delta^{13} \mathrm{C}\right)$. Analytical precision based on routine analysis of the internal reference standard (Carrara Marble) and repeated measurements was $\pm 0.10 \%$ for $\delta^{18} \mathrm{O}$ and $\pm 0.05 \%$ for $\delta^{13} \mathrm{C}$.

Gender, left and right valves and life stages of the studied specimens of $C$. neglecta were separately measured to constrain their influence on isotopic fractionation. 


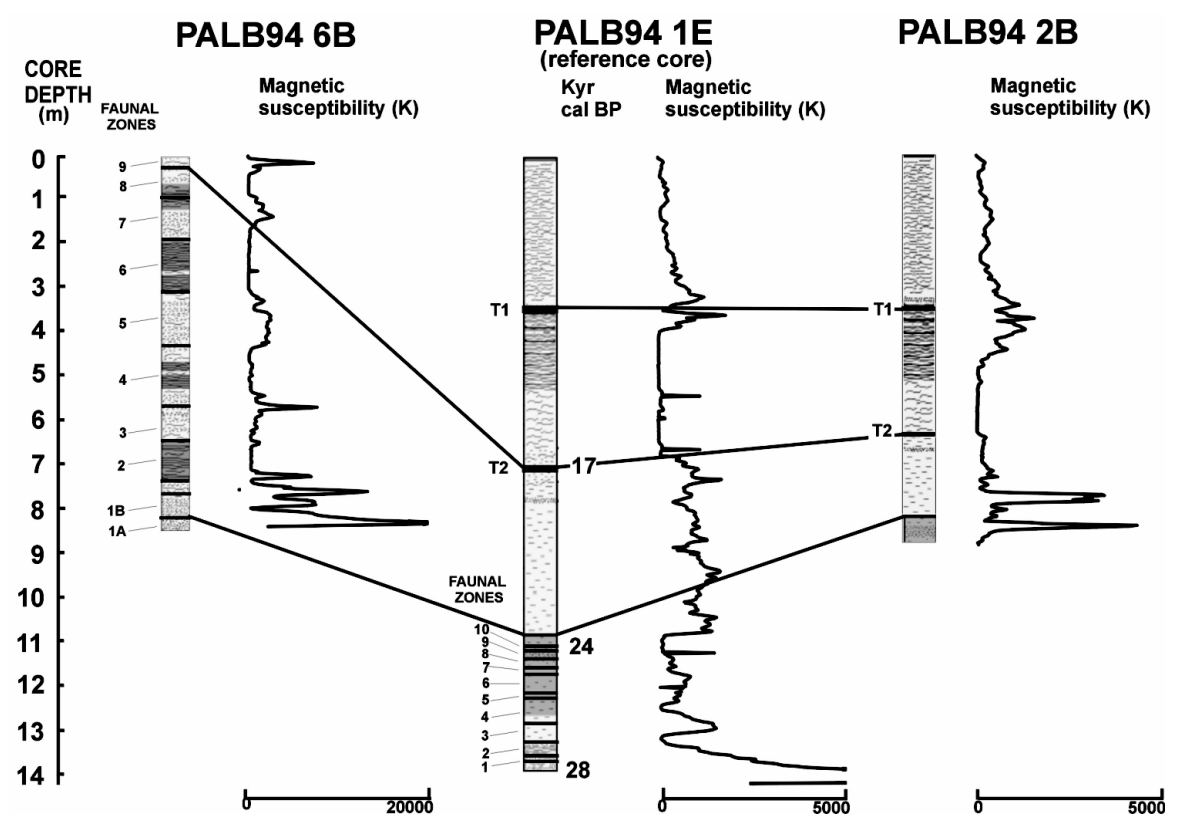

Fig. 2. Correlation of coring sites 1, 2, and 6 based on magnetic susceptibility (K; Rolph et al. 1996) and sedimentological features (Chondrogianni et al. 1996a). Faunal zones identified using invertebrate remains in sites 1 and 6 are also reported (Belis et al. 1999). $\mathrm{T} 1$ and $\mathrm{T} 2$ correspond to tephras AV (Avellino plinian eruption) and Y-1 (Biancavilla -Montalto event) respectively (Calanchi et al. 1996).

Water palaeotemperatures were calculated using the equilibrium isotopic fractionation factor for the calcitewater system (Friedman \& O'Neil 1977)

$$
1000 \ln (\Delta)=2.78\left(10^{6}\right) \mathrm{T}^{-2}-2.89
$$

where $1000 \ln (\Delta)=\delta^{18} \mathrm{O}$ calcite $-\delta^{18} \mathrm{O}$ water (SMOW), $(\Delta)=$ isotopic fractionation factor, $\mathrm{T}=$ temperature of the reaction $\left({ }^{\circ} \mathrm{K}\right)$. A $\delta^{18} \mathrm{O}$ surface lake water composition of $-0.3 \%$ (SMOW) was used (Chondrogianni et al. 1996b)

The $\delta^{18} \mathrm{O}$ composition of Candoninae valves was corrected for the vital offset using the coefficient +2.2 $\pm 0.15 \%$ o V-PDB (Von Grafenstein et al. 1992, 1999).

\subsection{Core correlation and chronological setting}

Site 2 is comparable to site 1 from a lithological point of view. The only major difference is that units in the lowermost half of core PALB94 2B appear more compressed than in core PALB94 1E (Fig. 2). In particular, the so-called ostracod sequence is relatively uniform, consisting of carbonate-rich light gray muds with a partially laminated structure.

The correlation of core PAL94 2B with those from sites 1 and 6 was made on the basis of lithology and high resolution magnetic susceptibility (Fig. 2). A tephra layer at $6.36 \mathrm{~m}$ in core PALB94 2B corresponds to the Etna Y-1 tephra identified at $7.2 \mathrm{~m}$ depth in core PALB94 1E and dated at $17.0 \pm 0.260 \mathrm{Kyr}$ cal BP (Calanchi et al. 1996; Chondrogianni et al. 2004).

A robust chronology emerges only through the combination of distinctive sedimentological features from each coring site. Matching these different environments represented by either littoral or pelagic sediments confirms an originally complex chronology when each site is considered individually.

Coring sites 2 and 1 are located at 55 and $70 \mathrm{~m}$ water depth, respectively (Figs 1 and 3 ). This $15 \mathrm{~m}$ difference in water depth may explain the simultaneous presence of littoral sediments in site 1 and the very slight occurrence or absence of lacustrine sediments in site 2 during the time interval preceding the major lake level rise identified $c a$ 24-23 Kyr cal BP (Guilizzoni et al. 2000). In addition, since littoral or sublittoral conditions dominated the sequence of site $6(25 \mathrm{~m}$ shallower than site 2) after the major rise in lake water level (Chondrogianni et al. 1996b; Manca et al. 1996), only deep lake deposits are possible in site 2 from $23 \mathrm{Kyr}$ cal BP onwards. Therefore, littoral - sublittoral deposits in this site, like those observed in the lowermost $45 \mathrm{~cm}$ of core PALB94 2B, are constrained within the time window in which the major rise of lake water level occurred (i.e., between 24 and $23 \mathrm{Kyr}$ cal BP).

\section{RESULTS}

\subsection{Ostracod abundance and assemblages}

Ostracod assemblages (reported in figure 4) were only found at $830-875 \mathrm{~cm}$ sediment depth. Candona neglecta is the most abundant species at the beginning of the ostracod sequence, whereas Ilyocypris bradyi dominates the uppermost $10 \mathrm{~cm}$. Other species such as Candona candida, Cypria ophtalmica, a number of species of the genus Potamocypris (namely $P$. villosa, $P$. pallida and $P$. zschokkei) and Herpetocypris sp. are rare. No decalcified valves are reported. 

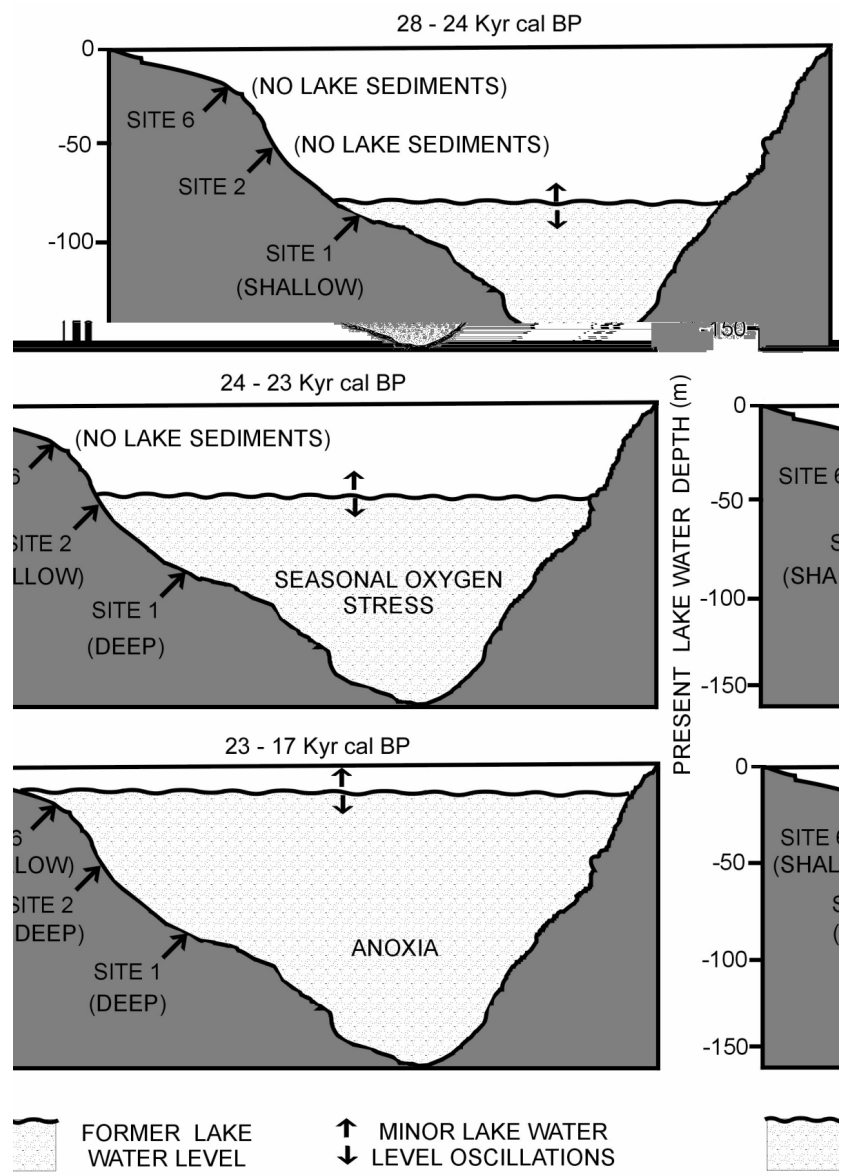

Fig. 3. The evolution of the lake water level between 28 and $17 \mathrm{Kyr}$ cal BP. Top: before $24 \mathrm{Kyr}$ cal BP the low lake water level created littoral-sublittoral conditions in site 1; no lake sediments deposited in sites 2 and 6 . Center: during the rise in lake water level a littoral - sublittoral environment dominated in site 2 whereas deep lake sediments were deposited in site 1; site 6 remained above the lake level. Bottom: after the major rise in lake water level, littoral conditions dominated in site 6; only deep lake deposits reached sites 1 and 2 . In addition to the described dominant trend, at each step there were minor lake water level oscillations.

PALB94 2B

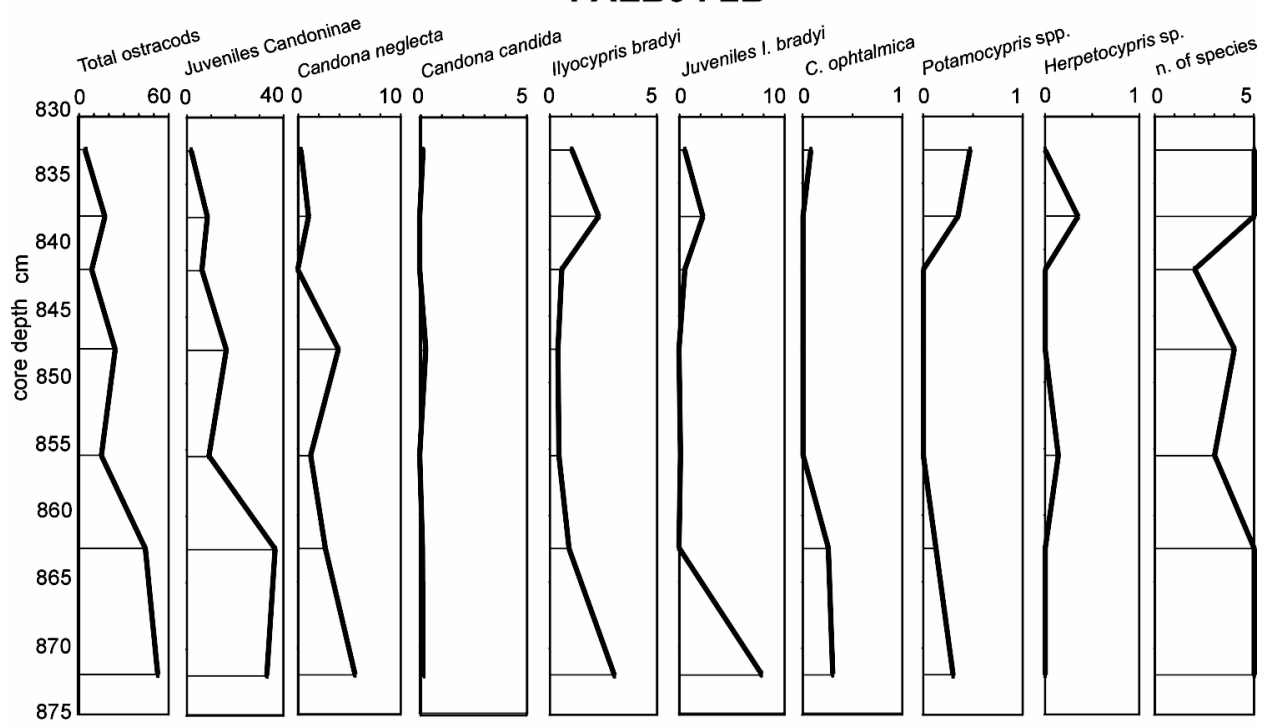

valves $\mathrm{g}^{-1} \mathrm{~d} . \mathrm{w}$.

Fig. 4. Ostracod species abundances in valves $\mathrm{g}^{-1}$ d.w. and number of species. 


\subsection{Oxygen and carbon stable isotopes}

The oxygen isotopic composition of adults of Candona neglecta ranges between $0.5 \%$ and $1.5 \%$, and in $I$. bradyi between $-2 \%$ and $-0.5 \%$ (Tab. 1 , Fig. 5). Isotopic values from adults of $C$. neglecta range between $1.5 \%$ and $-0.8 \%$ when corrected for vital effect using the factor $-2.2 \%$ o $( \pm 0.15)$ proposed by von Grafenstein et al. $(1992,1999)$.

\section{PALB94 2B}
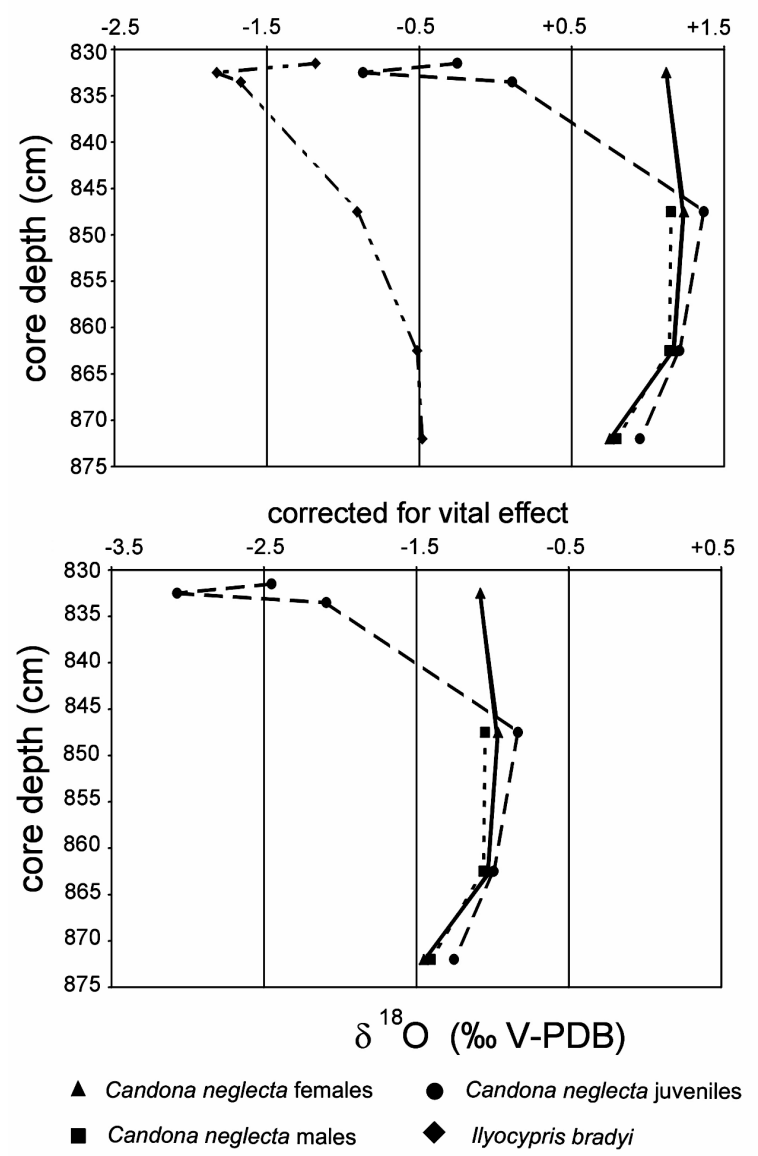

Fig. 5. $\delta^{18} \mathrm{O}$ in Candona neglecta, Ilyocypris bradyi and $C$. neglecta juveniles in \% V-PDB. The graph at the bottom shows values corrected for vital effect.

Isotopic values in left and right valves, in males and females of $C$. neglecta from a selected layer $(872 \mathrm{~cm}$ core depth), where the abundance of valves enabled us to run several replicates, are compared in table 2 . There are no significant differences in $\delta^{18} \mathrm{O}$ between left and right valves and between males and females (Fig. 6). Conversely, differences between adults and juveniles of C. neglecta (last larval stage) are appreciable. The latter presents isotopic compositions similar to those of the adult forms in the lower part of the sequence, shifting to values considerably lower than those of the adults in the uppermost $5 \mathrm{~cm}$ (Fig. 5). Significant interspecific differences are observed in uncorrected $\delta^{18} \mathrm{O}$ between $C$. neglecta and I. bradyi (Fig. 5).
The $\delta^{18} \mathrm{O}$ composition of adults of $C$. neglecta appears substantially uniform throughout the sequence. $I$. bradyi, on the other hand, presents a slightly decreasing trend along the entire time window. The juvenile forms of $C$. neglecta at the beginning of the sequence present a similar trend to that observed in the adults of the same species; however, in the uppermost $5 \mathrm{~cm}$ their values resemble those of I. bradyi.

The carbon isotopic signal is within the range 9.4\%o - $10.8 \%$ in adults and juveniles of $C$. neglecta, and between $9.8 \%$ and $11.3 \%$ for I. bradyi (Fig. 7).

C. neglecta females show a slightly increasing trend along the sequence, whereas the males of this species present a decreasing slope. Since values of $\delta^{13} \mathrm{C}$ in $C$. neglecta juveniles present a high intra-sample spreading, no trend is evident.

I. bradyi presents an increasing slope in the first half of the sequence, returning to the values observed at the bottom in the uppermost $5 \mathrm{~cm}$.

No significant differences are observed in $\delta^{13} \mathrm{C}$ between left and right valves at $872 \mathrm{~cm}$ sediment depth (Fig. 6, Tab. 2). Conversely, mean $\delta^{13} \mathrm{C}$ values from the valves of $C$. neglecta males appear slightly more positive ( $c a 0.5 \%$ ) than those of females of the same species. At $847 \mathrm{~cm}$ sediment depth, however, the situation is reversed, showing a $0.5 \%$ more positive mean composition for females than males (Fig. 7).

\subsection{Lake water temperature estimations}

Water palaeotemperatures were calculated assuming a water $\delta^{18} \mathrm{O}$ similar to that of present surface lake water $(-0.3 \%$ SMOW $)$. As expected, the estimated water temperatures show comparable trends to those already described in $\delta^{18} \mathrm{O}$. Temperatures estimated from juveniles and adults of $C$. neglecta present similar values and slopes in the lowermost $40 \mathrm{~cm}$ of the ostracod sequence. Estimated temperatures are slightly higher at the very beginning of the sequence $\left(8.5\right.$ to $9.5^{\circ} \mathrm{C}$ ), becoming relatively stable along the rest of the sequence ( 6.9 to $7.9{ }^{\circ} \mathrm{C}$ ) when only adult forms are considered. If the $\delta^{18} \mathrm{O}$ values are corrected for vital effects, the estimated temperatures rise to values between 18 and $20^{\circ} \mathrm{C}$ at the beginning of the sequence, remaining between 16 and $18^{\circ} \mathrm{C}$ for the rest of the studied interval.

In the uppermost $5 \mathrm{~cm}$ of the ostracod sequence, the estimated lake water temperatures from juvenile valves are higher than those estimated using adult valves $\left(12-16{ }^{\circ} \mathrm{C}\right.$ without vital effect, $22-27{ }^{\circ} \mathrm{C}$ with vital effect).

Estimated temperatures using I. bradyi isotopic compositions are markedly higher than those of adults of $C$. neglecta (considering isotopic signals not corrected for vital effect for both species). The observed difference of ca. $5{ }^{\circ} \mathrm{C}$ in estimated water temperature between these two species at the bottom of the ostracod sequence increases, reaching $c a 13{ }^{\circ} \mathrm{C}$ in the uppermost $5 \mathrm{~cm}$ of the sequence. 
Tab. 2. Comparison of isotopic signatures between males and females and between left and right valves from adults of the species $C$. neglecta at $872 \mathrm{~cm}$ depth in core PALB94 2B.

\begin{tabular}{lccccc}
\hline & $\delta^{13} \mathrm{C}$ & S.D. & $\delta^{18} \mathrm{O}$ & S.D. & $\mathrm{N}^{\circ}$ replicates \\
\hline males left & 10.63 & 0.03 & 0.73 & 0.08 & 2 \\
males right & 10.53 & 0.28 & 0.83 & 0.03 & 2 \\
females left & 10.06 & 0.52 & 0.83 & 0.19 & 4 \\
females right & 9.80 & 0.26 & 0.67 & 0.09 & 4 \\
total left & 10.25 & 0.50 & 0.80 & 0.16 & 6 \\
total right & 10.04 & 0.44 & 0.72 & 0.11 & 6 \\
\hline
\end{tabular}

\section{Candona neglecta - PALB94 2B $872 \mathrm{~cm}$}

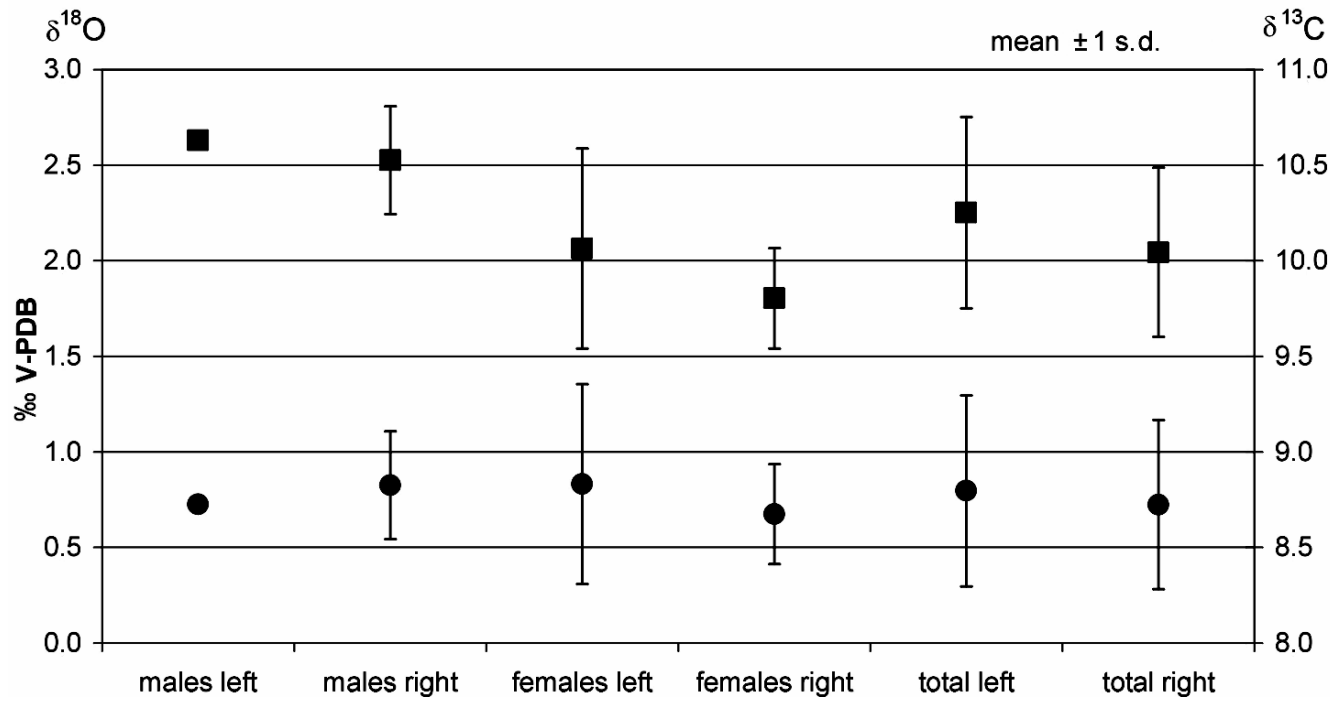

Fig. 6. Comparison of $\delta^{18} \mathrm{O}$ (dots) and $\delta^{13} \mathrm{C}$ (squares) signal from left and right valves and from males and females of Candona neglecta at $872 \mathrm{~cm}$ core depth. The overlapping error bars indicate no significant differences.

\section{PALB94 2B}

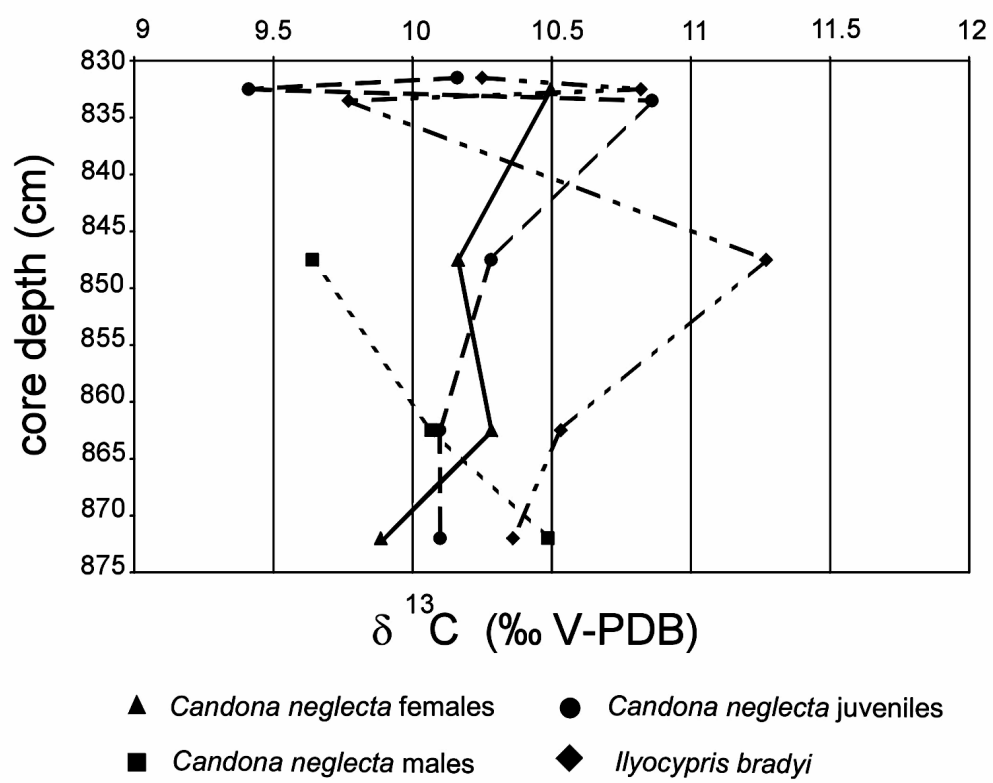

Fig. 7. $\delta^{13} \mathrm{C}$ in Candona neglecta, Ilyocypris bradyi and C. neglecta juveniles in \%o V-PDB. 
Although no changes are observed in C. neglecta adults in the uppermost $5 \mathrm{~cm}$ of the ostracod sequence, both juveniles of this species and I. bradyi shift to higher values.

\section{DISCUSSION}

\subsection{Variations in lake water level}

Lithological and petrophysical evidence such as magnetic susceptibility (Rolph et al. 1996) clearly indicates that the lowermost ca $2.5 \mathrm{~m}$ from core PALB94 2B represents full glacial sediments. The lowermost section in this core is similar to the sequence at the bottom of both site 6 (lithological unit IV) and site 1 (lithological units V to VII) (Chondrogianni et al. 1996a). Furthermore, in all three sequences the ostracod communities from these layers (see below) contain similar ostracod species assemblages indicative of littoral - sublittoral environments. However, taking into account the fact that there is a $40 \mathrm{~m}$ depth difference between the deepest and the shallowest coring sites, and considering the seismic interpretation and its calibration with core lithology (Chondrogianni et al. 1996a; Chondrogianni et al. 2004), the contemporary dominance of littoral conditions in all three sites can be excluded. Therefore, the succession of littoral - sublittoral environments as indicated by ostracod assemblages can be regarded as evidence of a stepwise filling of the lake basin (Fig. 3). Thus, magnetic susceptibility, lithology and biological evidence from ostracod remains in core PALB94 2B, retrieved in an intermediate location with respect to cores PALB94 1E and PALB9 6B (Fig. 1), are consistent with the hypothesis of lake level variation previously proposed in Belis et al. (1999) and Guilizzoni et al. (2000).

\subsection{The species assemblages}

Core correlation with sites 1 and 6 indicate that the ostracod sequence from core PALB94 2B (present study, $55 \mathrm{~m}$ water depth) is different in age than those previously studied in these sites (Fig. 2). However, the dominance of $C$. neglecta, the increasing abundance of I. bradyi and the decreasing trend of the total number of valves along the interval represented in the sequence under study suggest affinities with faunal zones 5, 6 and 7 from core PALB94 1E (site 1 - 70 m water depth, Belis et al. 1999). Analogously, the shift in dominance from C. neglecta to I. bradyi, the presence of the rare species Herpetocypris sp. and Potamocypris spp., and the absence of decalcified valves are similar observations to those within faunal zone 1A in core PALB94 6B (site 6 - $30 \mathrm{~m}$ water depth, Belis et al. 1999).

The autoecology of the species in the ostracod sequence indicates relatively cold conditions, as already reported with reference to the zones of cores from sites 1 and 6 (Fig. 1). The peaks in the abundance of $I$. bradyi at the beginning and end of this sequence $(872 \mathrm{~cm}$ and
$837 \mathrm{~cm}$ respectively), with the contemporary presence of Potamocypris pallida and Potamocypris zschokkei, indicate a lower lake water level with input of spring water. On the other hand, the dominance of $C$. neglecta and the reduction or disappearance of littoral species in the central part of the ostracod sequence $(863-842 \mathrm{~cm})$ provide evidence of either comparatively colder or deeper conditions.

The number of species and species abundance has been correlated to the ionic composition of the host water (De Deckker \& Forester 1988). According to these authors, specific diversity is low (around 5 species) when the concentration of $\mathrm{CO}_{3}^{-2}$ is below the calcite saturation level. In the sequence under study, although the number of species fluctuates slightly, there are never more than 5. This indicates that in this time window no marked changes in carbonate concentrations occurred and the water always remained below the calcite saturation level.

As previously suggested for site 1 by Belis et al. (1999), the definitive disappearance of ostracods from the sedimentary record is most likely related to seasonal oxygen stress, increased turbidity and reduced supply of dissolved carbonate in the near bottom waters. The temporal offset in the abundance of ostracod remains among sites is in agreement with the hypothesized changes in lake water level (Section 4.1).

\subsection{Oxygen isotopes}

No major excursion in the $\delta^{18} \mathrm{O}$ of $C$. neglecta adults is appreciable in the ostracod sequence from core PALB94 2B, whereas valves of $I$. bradyi present a gradual and steady decreasing trend. Although no correction factor for I. bradyi species has yet been established, the difference in the $\delta^{18} \mathrm{O}$ signal between the two dominant species may be at least partially related to their vital effects. In addition, since the shape and the slope of the oxygen isotopic signal along the sequence in these species are different, other species-related factors such as microhabitat and seasonality are likely to have influenced their isotopic signals

The shift in the uppermost $5 \mathrm{~cm}$ of the ostracod sequence of juveniles of $C$. neglecta, which in the rest of the sequence are comparable to the adults of the species, to values significantly lower and similar to those of $I$. bradyi, probably reflects a change in environmental conditions, as further discussed in section 4.6.

An estimation of $\delta^{18} \mathrm{O}$ in calcite precipitation in theoretical equilibrium with the present lake water at 20 $\mathrm{m}$ depth confirmed that isotopic composition of ostracod valves is quantitatively related to water $\delta^{18} \mathrm{O}$ and temperature. Taking into account measurements carried out in summer 1994 (Guilizzoni, pers. comm.) and in winter 1997 (Cioni et al. 2003) it was assumed that mean water temperature at that depth was $11{ }^{\circ} \mathrm{C}$. Lake water $\delta^{18} \mathrm{O}$ composition was estimated by interpolating the value of $-0.3 \%$ at water surface and $-0.55 \%$ at $30 \mathrm{~m}$ 
water depth measured in 1994 (Chondrogianni et al. 1996b).

The estimated $\delta^{18} \mathrm{O}$ for calcite in equilibrium was $0.3 \%$. Correcting this value with the disequilibrium factor for $C$. neglecta $(+2.2 \pm 0.15 \%$ V-PDB) adopted in this study produced a result very close to $\delta^{18} \mathrm{O}$ measurements on recent valves of $C$. neglecta adults collected at $20 \mathrm{~m}$ depth $(2.5 \%$; Chondrogianni et al. 1996b).

\subsection{Carbon stable isotopes}

Although species, gender and life stage show a fairly uniform $\delta^{13} \mathrm{C}$ composition at the beginning of the ostracod sequence, their evolution diverges as the sequence proceeds. The discrepancy between the carbon isotopic composition of species and between adults and juveniles of the same species may be related to differences in microhabitats or in seasonality. However, this interpretation is unlikely to explain the observed differences in gender.

As a whole, $\delta^{13} \mathrm{C}$ values in the authigenic and biogenic carbonates from the sediments of Lake Albano fall within the range for freshwater environments but appear higher than those commonly observed in lakes in Central Europe (e.g., Lister 1988; Schwalb et al. 1994; von Grafenstein et al. 1999). As far as authigenic calcite is concerned, this situation has been linked to diagenetic precipitation in the methanogenic zone of organic matter degradation, leading to the precipitation of ${ }^{13} \mathrm{C}$ enriched carbonates (Chondrogianni et al. 1996b).

High $\delta^{13} \mathrm{C}$ signatures in carbonates have already been reported in other volcanic lakes (Schwalb et al. 1999; Schwalb 2003; Lamb et al. 2000). In addition, the ${ }^{14} \mathrm{C}$ depletion and ${ }^{13} \mathrm{C}$ enrichment of waters in a volcanic region in north-eastern California have been related to their interaction with dead carbon originating from volcanic $\mathrm{CO}_{2}$ (Rose et al. 1996).

A study on the present water chemistry of Lake Albano revealed that, due to the contribution from vents of deep origin, there are high concentrations of $\mathrm{CO}_{2}$ in the lake water below $70 \mathrm{~m}$ (Cioni et al. 2003). Though documentary evidence is not yet available, the authors hypothesize that a lowering of the epilimnetic temperature below $8.5^{\circ} \mathrm{C}$ or seismic activity can periodically induce a full overturn of the water column, which is likely to lead to an increase in $\mathrm{CO}_{2}$ concentrations in the shallow waters and occasionally to a release of this gas into the atmosphere (degassing). However, there is no evidence of such phenomena in the Holocene sediments that have been studied in the framework of the PALICLAS project (Ariztegui et al. 2001).

The lake level during the time window under analysis was substantially lower than it is at present, so that circulation of the water column was probably more frequent. Hence, the contribution of $\mathrm{CO}_{2}$ from deep vents probably had more influence on the composition of DIC in the whole water column and, therefore, on the isotopic signal of the carbonates in the sediments of the lake. Further evidence of the influence of volcanic $\mathrm{CO}_{2}$ on lake carbonates comes from a number of ${ }^{14} \mathrm{C}$ radiocarbon datings on bulk carbonates that were discarded because they appeared too old compared with other more reliable datings (hard water effect).

\section{5. $\delta^{18} O / \delta^{13} \mathrm{C}$ cross plot}

A $\delta^{18} \mathrm{O}$ versus $\delta^{13} \mathrm{C}$ cross plot clearly separates the C. neglecta and I. bradyi populations (Fig. 8). The latter species shows more negative and widespread $\delta^{18} \mathrm{O}$ values, whereas both male and female specimens of $C$. neglecta fall within a relatively narrow range of $\delta^{18} \mathrm{O}$ values. The difference among centroids of speciesclusters is $c a 2 \%$ for $\delta^{18} \mathrm{O}$ axis but only $0.5 \%$ for $\delta^{13} \mathrm{C}$. Interestingly, the clusters overlap when $C$. neglecta values corrected for vital effect are plotted. Predictably, the calcite of juveniles of $C$. neglecta from the lowermost part of the ostracod sequence falls within the $C$. neglecta adults-cluster, whereas juveniles of $C$. neglecta from the uppermost $5 \mathrm{~cm}$ plot within the I. bradyicluster.

Talbot (1990) has interpreted the covariance between $\delta^{18} \mathrm{O}$ and $\delta^{13} \mathrm{C}$ in carbonates as typical of hydrologically closed lakes. In carbonates of biogenic origin this covariance is, however, often masked by local factors influencing the DIC pool, so that $\delta^{13} \mathrm{C}$ varies more erratically. This may explain the weak covariation between oxygen and carbon stable isotopes in a closed lacustrine basin with a long water residence time, like Lake Albano.

\subsection{Estimated water temperature and $\delta^{18} \mathrm{O}$}

Analyses by Chondrogianni et al. (1996b) on valves of Candona neglecta from core PALB94 6B provided inferred bottom water temperatures based upon vital effect corrected isotopic measurements up to $c a 17{ }^{\circ} \mathrm{C}$. These estimations, which have been considered unrealistically high, imply that (a) the ostracod valves were deposited in environments shallower than $10 \mathrm{~m}$, (b) the present lake water $\delta^{18} \mathrm{O}$ signature is substantially different from that of the time window represented in the sequence under study. Since there is no evidence to support the first hypothesis, the second one may be regarded as worthy of further investigation. Hence, we propose a scenario for estimating the extent of the excursion in water $\delta^{18} \mathrm{O}$ within the sequence under study, based on ostracod autoecology.

The algorithm proposed by Friedman \& O'Neil enables the lake water temperature at the time of calcite precipitation to be estimated by measuring the oxygen isotopic composition of authigenic (or biogenic) calcite, provided the isotopic composition of the water is known. Conversely, the oxygen isotopic composition of the lake water can be estimated if the water temperature is known. 


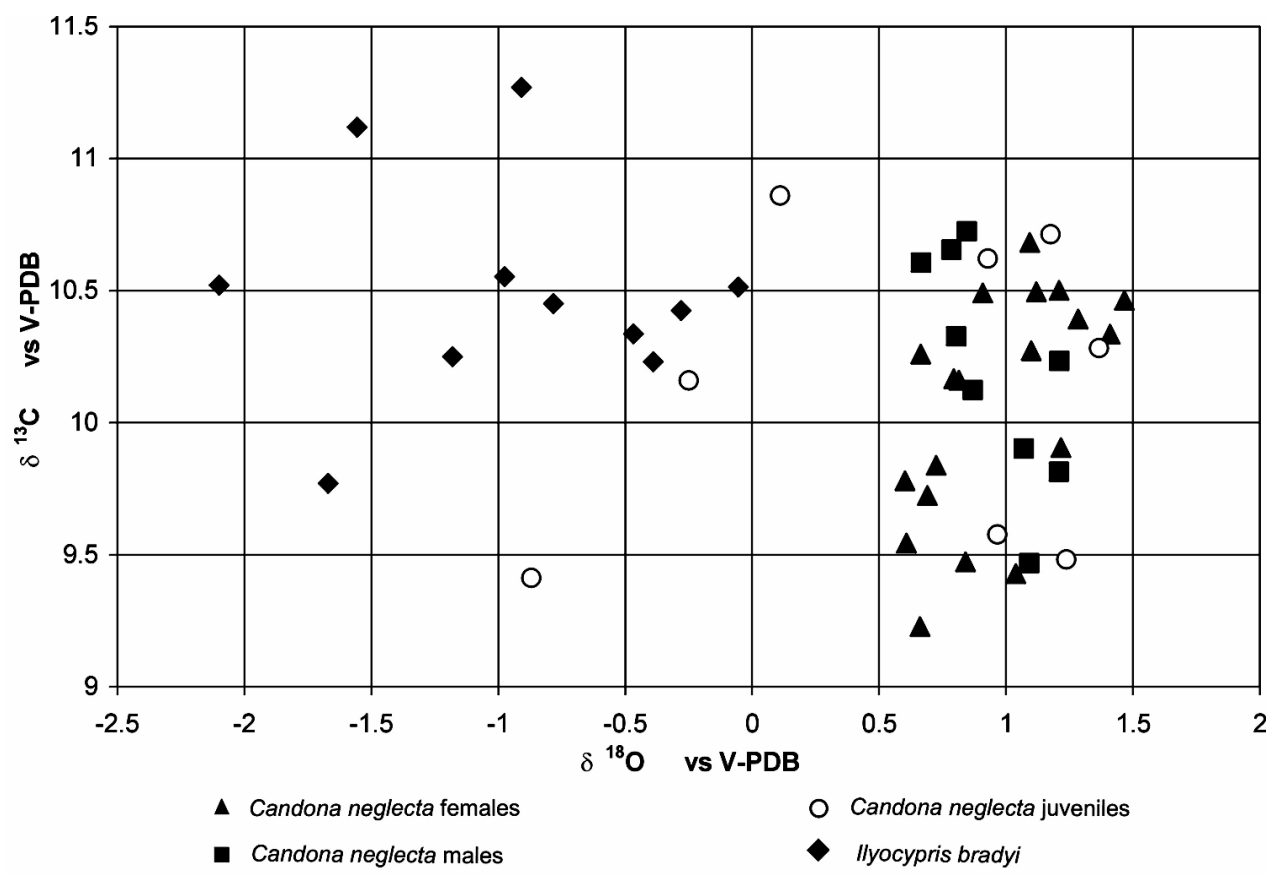

Fig. 8. Cross plot of $\delta^{18} \mathrm{O}$ versus $\delta^{13} \mathrm{C}$ in ostracod calcite in core PALB94 2B.

C. neglecta prefers cold waters, even though it tolerates water temperatures up to $20{ }^{\circ} \mathrm{C}$ for short periods. It is present in many types of environments including springs and lakes. Hiller (1972), describing the autoecology of a number of species from northern Germany, concluded that the life history of $C$. neglecta depends on the kind of environment it lives in. In the littoral of lakes, adults appear only in autumn and winter, whereas juveniles are present all year round.

Since this species dwells in or near bottom waters where temperature is relatively constant, especially during the winter, we can reasonably assume that adults of C. neglecta in the different parts of the ostracod sequence precipitated their valves at a constant temperature. Since this temperature is not known for certain, this hypothesis does not provide the means to estimate absolute values of lake water $\delta^{18} \mathrm{O}$; however it does enable us to perceive relative changes.

Except for a slight increase between $872 \mathrm{~cm}$ and 862 $\mathrm{cm}$, no changes in oxygen isotopic composition of the lake water along the whole ostracod sequence can be seen from C. neglecta adults.

A similar estimation was made using the last larval stages of the same species, representing not only autumn-winter conditions, as do the adults, but also the warmer season. In the lower part of the sequence the estimated trends from juveniles and adults are identical, indicating that water $\delta^{18} \mathrm{O}$ was stable not only in winter but also on a yearly basis. In contrast, in the upper $5 \mathrm{~cm}$ of the ostracod sequence water $\delta^{18} \mathrm{O}$ estimations from juveniles are 1-2\%o lower than those from the lowermost part of the sequence, indicating a change affecting annual means (juveniles) but not winter means (adults).
Such a difference between juveniles and adults of the same species suggests an increase in water temperatures or the inflow of water containing a lower isotopic composition that did not affect the cold season. In addition, water $\delta^{18} \mathrm{O}$ estimations obtained from $I$. bradyi, a species present throughout the year, are consistent with those obtained from juveniles of $C$. neglecta.

\subsection{Environmental reconstruction}

By combining the ecological and isotopic data from the ostracods it is possible to identify three major zones within the ostracod sequence.

Zone A $(872-860 \mathrm{~cm})$ : the ostracod assemblage indicates a relatively shallow environment with influx of springs. The scenario is consistent with information from oxygen isotopes in C. neglecta adults and juveniles, which are slightly lower than the mean of the whole ostracod sequence, indicating either a slightly higher water temperature or a slightly lower water $\delta^{18} \mathrm{O}$ composition than in the overlying zone. Concentrations of $\delta^{13} \mathrm{C}$ in both species are similar and close to the average of the ostracod sequence.

Zone B $(860-840 \mathrm{~cm})$ : littoral species have become rare or absent, indicating a probable increase in lake water level. These changes in the environmental conditions would lead to lower and more stable water temperature at the coring site. Few changes in ostracod oxygen isotopes are displayed in this time window; values appear to be substantially stable in both species. Data on $\delta^{13} \mathrm{C}$ are in contrast; although $C$. neglecta females and juveniles do not show any significant varia- 


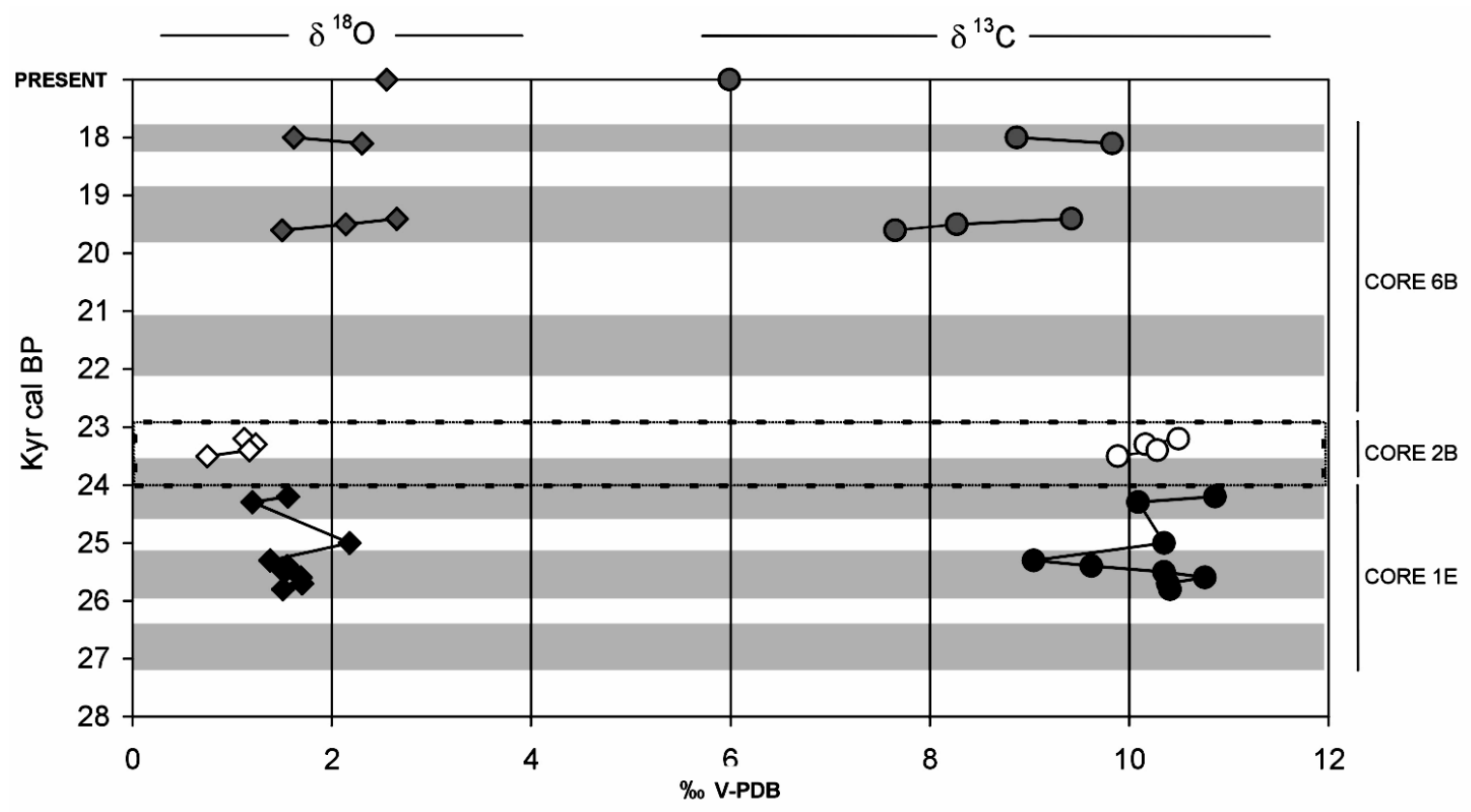

Fig. 9. The $\delta^{18} \mathrm{O}$ and $\delta^{13} \mathrm{C}$ in Candona neglecta from site 2 (this study) and sites 1 and 6 (Chondrogianni et al. 1996b) of Lake Albano (white, black and grey symbols, respectively). Data are plotted using the chronological framework proposed by Guilizzoni et al. (2000) and Chondrogianni et al. (2004). Present values are reported at the top of the graph. Shaded areas represent warmer phases with increased lake biological productivity. The dotted line indicates the phase of the major rise in lake water level.

tions with respect to the previous zone, there is a decrease in C. neglecta males and an increase in I. bradyi.

Zone C $(840-830 \mathrm{~cm})$ : the ostracod assemblage indicates a littoral environment rich in vegetation, with influx of springs suggesting a lowering of lake water level. At this level, although $\delta^{18} \mathrm{O}$ in C. neglecta adults does not show any variations compared to the previous zone, the concentration of $\delta^{18} \mathrm{O}$ in juveniles of this species and in I. bradyi shifts to significantly lower values. This may be related either to increased summer temperatures or to a seasonal decrease in water $\delta^{18} \mathrm{O}$ (not affecting autumn-winter means). No significant changes are observed in the $\delta^{13} \mathrm{C}$ from $C$. neglecta adults, whereas concentrations in I. bradyi and C. neglecta juveniles are similar to the values observed at the beginning of the ostracod sequence.

Changes affecting only summer temperatures were reported by Follieri et al. (1988) in a 250,000 year pollen record from Valle di Castiglione, also located in Central Italy.

In lakes Ammersee and Starnberg (Germany) von Grafenstein et al. (1999) observed that differences in $\delta^{18} \mathrm{O}$ between adults and juveniles in $F$. levanderi and $C$. candida (Candoninae) decrease with increasing water depth. Thus, a lowering in the lake water level should be recorded as a diverging trend between the oxygen isotopic signals of adults and juveniles. This feature is clear in the upper $5 \mathrm{~cm}$ of the ostracod sequence under study and is consistent with the evidence on lake water level evolution based upon the analyses of the ostracod species assemblages. Furthermore, the two alternative hypotheses proposed for zone C (i.e., lowering of lake level and increase in mean summer temperatures) are in fact complementary, since in modern systems these variables are very often closely correlated.

\subsection{The evolution of stable isotopes in the Latest Pleistocene}

By combining oxygen and carbon stable isotope data in $C$. neglecta valves from site 2 (present study) and sites 1 and 6 (Chondrogianni et al. 1996b) with the chronological model proposed by Guilizzoni et al. (2000) and Chondrogianni et al. (2004), we can identify the major trends between 28 and $17 \mathrm{Kyr}$ cal $\mathrm{BP}$ and compare past with present signatures (Fig. 9). This time window is of special interest, since it shows millennial to centennial scale oscillations in lake water level and lake biota which are regarded as responses to climate forcing (Guilizzoni et al. 2000; Chondrogianni et al. 2004). Unfortunately, the presence of ostracods in these sediments is not continuous. In core $6 \mathrm{~B}$ in particular, ostracods are present only in the phases of warmer climate and increased lake productivity which are also characterised by an appreciable excursion in both oxygen and carbon isotopic signals.

Excepting a positive excursion at $\mathrm{ca} 25 \mathrm{Kyr}$ cal BP, $\delta^{18} \mathrm{O}$ values between 28 and $24 \mathrm{Kyr}$ cal BP were relatively constant. During the major rise in lake water level (24 - $23 \mathrm{Kyr}$ cal BP), oxygen isotopic signals are slightly lower than those observed in the previous time window. This difference may be related to a change in the precipitation-evaporation balance that probably led 
to the rise in lake water level. After this event, $\delta^{18} \mathrm{O}$ values are higher, and closer to the present day value of $2.5 \%$ V-PDB.

Changes in $\delta^{13} \mathrm{C}$ are even more evident. There is a decreasing trend along this time window. Values that ranged between 9 and 11\% V-PDB before and during the major rise in lake water level shift to values between 7 and $10 \%$ V-PDB after that event. Present $\delta^{13} \mathrm{C}$ signatures are even lower (around 6\% V-PDB).

The decrease in $\delta^{13} \mathrm{C}$ during one of the minor warmer oscillations identified between $c a 26$ and $c a 25$ $\mathrm{Kyr}$ cal BP probably reflects a transition from a relatively productive environment, where the $\mathrm{CO}_{2}$ uptake by photosynthesis was dominant, to a situation with low oxygen concentration in the bottom waters where bacteria sulphate reduction took place. The presence of sulphur photosynthetic bacteria pigments in this phase supports this hypothesis (Guilizzoni et al. 2000). The peak in ostracod abundance and $\delta^{18} \mathrm{O}$ values at $c a 25$ Kyr cal BP may reflect a short climatic amelioration within a colder phase, although this hypothesis cannot be supported with evidence from other proxies.

A comparison of $\delta^{18} \mathrm{O}$ with full glacial ostracod sequences from other European sites highlights the fact that values from Lake Albano are relatively high. Lister (1988) reported C. candida and Cytherissa lacustris from Lake Zurich (Switzerland) with $\delta^{18} \mathrm{O}$ compositions ranging between -10 and $-12 \%$; von Grafenstein et al. (1992) reported values between -12 and $-8 \%$ for $C$. neglecta and C. lacustris in Lake Starnberg (Germany); and Schwalb et al. (1994) obtained values ranging between -6 and $-11 \%$ for Limnocythere sanctipatricii and Limnocythere mirabilis in Lake Neuchâtel (Switzerland). While the comparison of values obtained in different sites is not straightforward due to the different species considered and the influence of local factors (such as glacial meltwater input) the relatively high isotopic signal in Lake Albano very likely reflects a relatively higher influence of moisture from the Mediterranean Sea, as it is in present day major European atmospheric circulation patterns (e.g., Rozansky et al. 1993 and McKenzie 1993).

\section{CONCLUSIONS}

The results of our study indicate that in the Lake Albano ostracod sequence no significant differences in the stable oxygen or carbon isotopic signals can be associated to gender or the side of the carapaces.

As reported in the literature, there are significant differences between the life stages within a single species and between species which are not closely related. This means that experimental studies on living specimens designed to quantify the specific vital effect are essential if quantitative temperature and isotopic reconstructions are to be made. Ostracod valves in full- and late-glacial sediments of Lake Albano present relatively high values of $\delta^{13} \mathrm{C}$, and different species and genders provide con- trasting evidence. In addition, the lack of covariance between $\delta^{13} \mathrm{C}$ and $\delta^{18} \mathrm{O}$ indicates that evaporation is not the main factor governing lake water isotopical composition. Hence, an influence on lake water chemistry of springs containing a $\mathrm{CO}_{2}$ gas phase cannot be excluded. These findings suggest that the dynamics of carbon isotopes in this environment requires further comprehensive and specific research that is beyond the scope of this paper.

Changes in water chemistry that may have affected the carbon isotopic signature of the ostracods apparently did not affect the oxygen isotopic signal, since at least one species ( $C$. neglecta adults) living in an environment with relatively constant temperature provided a signal that is stable along the whole ostracod sequence.

Finally, the ostracod data indicate minor lake water level oscillations (10-15 m of water depth) during the major rise in lake water level between 24 and $23 \mathrm{Kyr}$ cal BP. The present lack of a detailed chronology for the sequence under analysis is an obstacle to comparison with other high resolution records. However, the short term variations described in this study are consistent with other multiproxy evidence of rapid climatic changes during the last full glacial in Lake Albano (Guilizzoni et al. 2000; Chondrogianni et al. 2004). The results presented in this study demonstrate that the isotopic signal in ostracod valves can be better interpreted and understood by matching it to environmental information obtained from the analysis of species assemblages.

\section{ACKNOWLEDGMENTS}

We are grateful to Prof. J.A. McKenzie for her scientific hospitality at the ETH-Zurich during the first author visit at this institution. We appreciate the help of $\mathrm{S}$. Bernasconi at the isotope lab. Special thanks to P. Guilizzoni and M. Filippi for their helpful and critical comments on an early version of the manuscript. We also thank A. Schwalb for her constructive review that contributed to improving the manuscript. This study was partially supported by a scholarship granted to the first author in the framework of the research exchange programme between the Italian National Research Council (C.N.R.) and the Swiss National Science Foundation (F.N.S).

\section{REFERENCES}

Ariztegui, D., C. Chondrogianni, A. Lami, P. Guillizoni, \& E. Lafargue. 2001. Lacustrine organic matter and the Holocene paleoenvironmental record of Lake Albano (central Italy). J. Paleolimnol., 26(3): 283-292.

Belis, C.A., A. Lami, P. Guilizzoni, D. Ariztegui \& W. Geiger. 1999. The late Pleistocene ostracod record of the crater lake sediments from Lago di Albano (Central Italy): changes in trophic status, water level and climate. $J$. Paleolimol., 21: 151-169.

Boni, C., P. Bono, S. Lombardi, L. Mastrorillo \& C. Percolo. 1995. Hydrogeology, fluid geochemistry and thermalism. In: R. Trigila (Ed.), The Volcano of the Alban Hills. Rome: 221- 242 . 
Cioni, R., M. Guidi, B. Raco, L. Marini \& B. Gambardella. 2003. Water chemistry of Lake Albano (Italy). Journal of Volcanology and Geothermal Research, 120: 179-195.

Calanchi, N., E. Dinelli, F. Lucchini \& A. Mordenti. 1996. Chemostratigraphy of late Quaternary sediments from Lake Albano and central Adriatic Sea cores (PALICLAS project). Mem. Ist. ital. Idrobiol., 55: 247-263.

Chondrogianni, C., D. Ariztegui, F. Niessen, C. Ohlendorf \& G.S. Lister. 1996a. Late Pleistocene and Holocene Sedimentation in Lake Albano and Lake Nemi (Lazio, Central Italy). Mem. Ist. ital. Idrobiol., 55: 22-38.

Chondrogianni, C., D. Ariztegui, S.M. Bernasconi, E. Lafargue \& J.A. McKenzie. 1996b. Geochemical indicators tracing ecosystem response to climate change during the late Pleistocene (Lake Albano, central Italy). Mem. Ist. ital. Idrobiol., 55: 99-110.

Chondrogianni, C., D. Ariztegui, T. Rolph, S. Juggings, A. Shemesh, M. Rietti-Shati, F. Niessen, P. Guilizzoni, A. Lami, J.A. McKenzie \& F. Oldfield. 2004. Millennial to interannual climate variability in the Mediterranean during the Last Glacial Maximum. Quaternary International, 122: 31-41.

De Deckker, P. \& R.M. Forester. 1988. The use of ostracods to reconstruct continental Palaeoenvironmental records. In: P. De Deckker, J. P. Colin \& J. P. Peypouquet (Eds), Ostracoda in the earth sciences. Elsevier Amsterdam: 175-199.

Follieri, M., D. Magri, \& L. Sadori. 1988. 250,000-Year Pollen Record from Valle di Castiglione (Roma). Pollen et Spores, 30(4-5): 329-356.

Friedman, I. \& J.R. O'Neil. 1977. Compilation of stable isotope fractionation factors of geo-chemical interest. In: Data of Geochemistry. 6th ed. U.S. Geol. Surv. Prof. Paper. KK1-KK12.

Guilizzoni, P. \& F. Oldfield (Eds). 1996. Palaeoenvironmental Analysis of Italian Crater Lake and Adriatic Sediments (PALICLAS). Mem. Ist. ital. Idrobiol., 55: $357 \mathrm{pp}$.

Guilizzoni, P., A. Marchetto, A. Lami, F. Oldfield, M. Manca, C.A. Belis, A.M. Nocentini, P. Comoli, V. J. Jones, S. Juggins, C. Chondrogianni, D. Ariztegui, J.J. Lowe, D.B Ryves, R.W. Battarbee, T.C. Rolph \& J. Massaferro. 2000. Evidence for short-lived oscillations in the biological records from the sediments of Lago Albano (Central Italy) spanning the period $\mathrm{ca} 28$ to $17 \mathrm{k}$ yr BP. J. Paleolimnol., 23: 117-127.

Hiller, D. 1972. Untersuchugen zur Biologie un zur Ökologie limnischer Ostracoden aus der umgeung von Hamburg. Arch. Hydrobiol., Suppl. 40: 400-497.

Lamb, A.L., M.J. Leng, H.F. Lamb \& M. Umer Mohammed. 2000. A 9000-year oxygen and carbon isotope record of hydrological change in a small Ethiopian crater lake. The Holocene, 10: 167-177.

Lister, G.S., 1988. Stable isotopes from lacustrine Ostracoda as tracers for continental Paleoenvironments. In: P. De Deckker, J. Colin \& J. Peypouquet (Eds), Ostracoda in the Earth Sciences. Elsevier, Amsterdam: 201-218.

Manca, M., A.M. Nocentini, C.A. Belis, P. Comoli \& L. Corbella. 1996. Invertebrate fossil remains as indicators of late Quaternary envirnomental changes in Ltium crater lakes (L. Albano and L. Nemi). Mem. Ist. ital. Idrobiol., 55: 149-176.

Mastrigli, A. 1964. Dalla Antica Albalonga alla moderna Albano. 30 secoli di avvenimenti nel quadro della storia d'Italia. Roma.

McKenzie, J.A. 1993. Pluvial conditions in the eastern Sahara following the penultimate deglaciation: implications for changes in atmospheric circulation patterns with global warming. Palaeogeography, Palaeoclimatology, Palaeoecology, 103: 95-105.

McKenzie, J., A. \& G. Eberli. 1987. Indications for abrupt Holocene climatic change: Late Holocene oxygen isotope stratigraphy of the Great Salt lake, Utah. In: W.H. Berger \& L. Labeyrie (Eds), Abrupt Climatic Change: Evidence and Implications. NATO ASI Ser. C. Math. Phys. Sci, 216. Reidel, Dordrecht: 127-136.

McKenzie, J.A. \& D.J. Hollander. 1993. Oxygen-isotope record in recent carbonate sediments form Lake Greifen, Switzerland (1750 - 1986): application of continental isotopic indicator for evaluation of changes in climate and atmospheric circulation patterns. In: Swart, P.K., K.C. Lohamann, J.A. McKenzie \& S. Savin (Eds), Climate Change in Continental Isotopic Records. Geophys. Monograph, 78: 101-111

Mullins, H.T. 1998. Environmental change controls of lacustrine carbonates, Cayuga Lake, New York. Geology, 26: 443-446.

Rolph, T., F. Oldfield \& K.D. van der Post. 1996. Palaeomangetism and rock-magnetism results from Lago di Albano and Adriatic Sea (Italy). Mem. Ist. ital. Idrobiol., 55: 265-284.

Rose, T.P., M.L. Davisson \& R.E. Criss. 1996. Isotope hydrology of voluminous cold springs in fractured rock from an active volcanic region, northeastern California. $J$. Hydrol:: 179: 207-236.

Rozansky, K., L. Araguás-Araguás, R. Gonfiantini. 1993. Isotopic Patterns in Modern Global Precipitation. In: Swart, P.K., K.C. Lohamann, J.A. McKenzie \& S. Savin (Eds), Climate Change in Continental Isotopic Records. Geophys. Monograph, 78: 1-36.

Schwalb, A. 2003. Lacustrine ostracodes as stable isotope recorders of late-glacial and Holocene environmental dynamics and climate. J. Paleolimnol., 29: 265-351.

Schwalb, A., S.J. Burns \& K. Kelts. 1999. Holocene environments from stable isotope stratigraphy of ostracods and authigenic carbonate in Chilean Altiplano Lakes. Palaeogeography, Palaeoclimatology, Palaeoecology, 148: 153168.

Schwalb, A. \& W.E. Dean. 1998. Stable isotopes and sediments from Pickerel Lake, South Dakota, USA: a $12 \mathrm{Kyr}$ record of environmental changes. J. Paleolimnol., 20: 1520.

Schwalb A., G. S. Lister \& K. Kelts. 1994. Ostracod carbonate $\delta^{18} \mathrm{O}$ - and $\delta^{13} \mathrm{C}$ - signatures of hydrological and climatic changes affecting Lake Neuchatel, Switzerland, since the latest Pleistocene. J. Paleolimnol., 11: 3-17.

Schwalb, A., S.J. Burns, G. Cusminsky, K. Kelts \& V. Markgraf. 2002. Assemblage diversity and isotopic signals of modern ostracodes and host waters from Patagonia, Argentina. Palaeogeography, Palaeoclimatology, Palaeoecology, 187: 323-339.

Talbot, M.R.. 1990. A review of the palaeohydrological interpretation of carbon and oxygen isotopic ratios in primary lacustrine carbonates. Chem. Geol. (Isot. Geosci. Sect.), 80: 261-279.

Talbot, M.R. \& K. Kelts. 1990. Palaeolimnological signatures from carbon and oxygen isotopic ratios in carbonates from organic-rich lacustrine sediments. In: B.J. Katz \& M.R. Talbot (Eds), Lacustrine exploration: Case Studies and Modern Analogs. Am. Assoc. Pet. Geol. Mem., 50: 99112.

Teranes, J.L. \& J.A. McKenzie. 2001. Lacustrine oxygen isotope reord of $20^{\text {th }}$-century climate change in central Europe: evaluation of climatic controls on oxygen isotopes in precipitation. J. Paleolimnol., 26: 131-146.

Teranes, J.L., J.A. McKenzie, S.M. Bernasconi, A.F. Lotter \& M. Sturm. 1999a. A study of oxygen isotopic fractionation during bio-induced calcite precipitation in eutrophic Baldeggersee, Switzerland. Geochem. Cosmochem. Acta, 63: 1981-1989.

Teranes, J.L. , J.A. McKenzie, A.F. Lotter \& M. Sturm. 1999b. Stable isotope response to lake eutrophication: Calibration of a high-resolution lacustrine sequence of 
Baldeggersee, Switzerland. Limnol. Oceanogr., 44(2): 320-333.

Trigila, R. (Ed.). 1995. The Volcano of the Alban Hills. Rome: $283 \mathrm{pp}$.

Urey, H.C., H.A. Lowenstan, S. Epstein \& C.R. McKinney. 1951. Measurement of paleotemperatures and temperatures of the Upper Cretaceous of England, Denmark and the southeastern United States. Bull. Geol. Soc. Am., 62: 399-416.

von Grafenstein, U., H. Erlernkeuser \& P. Trimborn. 1999. Oxygen and carbon isotopes in modern fresh-water ostracod valves: assessing vital offsets and autoecological effects of interest for palaeoclimate studies. Palaeogeography, Palaeoclimatology, Palaeoecology, 148: 133-152.

Received: April 2004

Accepted: September 2004 von Grafenstein, U., H. Erlenkeuser, J. Müller \& A. Kleinmann-Eisenmann. 1992. Oxygen isotope records of benthic osracodes in Bavarian lakes sediments: Reconstruction of late and post glacial temperatures. Naturwissenchaften, 79: 145-152.

von Grafenstein, U., U. Eicher, H. Erlenkeuser, P. Ruck, J. Schwander \& B. Ammann. 2000. Isotope signature of the Younger Dryas and two minor oscillations at Gerzensee (Switzerland): palaeoclimatic and palaeolimnologic interpretation based on bulk and biogenic carbonates. Palaeogeography, Palaeoclimatology, Palaeoecology, 159: 215229. 